\title{
Adult Education, the Use of Information and Communication Technologies and Their Impact on Elderly's Quality of Life: A Case Study
}

\author{
Elenka Brenna \\ Department of Economics and Management \\ Università degli Studi di Pavia,Via San Felice, 5 \\ 27100 Pavia
}

\begin{abstract}
In recent years, there has been a growing interest among scholars on Information and Communication Technologies (ICT) and their beneficial effects on elderly wellbeing; almost all contributions support the positive impact of ICT on the older population because their use has been demonstrated to enhance social participation and psychosocial wellbeing.This study contributes to the extant literature by using a specific and comprehensive measure of quality of life, the WHOQol-Bref, on a sample of 341 individuals attending the University of Third Age in an Italian town. Three different model specifications were built in order to test the impact of different aspects of ICT use on elderly's quality of life, respectively: i) frequency of ICT use, ii) location of ICT use and iii) kind of ICT used. Results corroborate the findings of existing literature and provide insights on policy measures aimed at favoring a process of active ageing across western countries.
\end{abstract}

Keywords: ICT, active ageing policies, quality of life, WHOQol-Bref, OLS.

\section{Introduction}

In 2016, people aged 65 year or older accounted for more than $20 \%$ of the total population in three European countries: Italy (22\%), Germany $(21.3 \%)$ and Greece $(21.1 \%)$. This figure is $19.2 \%$ at the European level and it is expected to rise to $28 \%$ by 2060 (Eurostat, 2016). Concomitant with population ageing has been the rise of healthcare and economic issues due to the progressive deterioration of individual health. As age increases, the probability of being exposed to chronic and degenerative diseases rises, limiting individual autonomy and augmenting the need of care (Brenna and Di Novi, 2016). The governments of several industrialized countries have adopted active ageing policies to reduce the societal burden of the increasingly mature population, and to better guarantee older adults an adequate quality of life (QoL).

Active ageing is defined by the World Health Organization (WHO) as "the process of optimizing opportunities for health, participation and security in order to enhance quality of life as people age" (WHO, 2002). An active ageing approach seeks to enhance QoL in three main ways: by decreasing the probability of disease and disease-related disability, contributing to the development of cognitive and physical functional capacity, and promoting active engagement with life. The challenge for governments consists in identifying strategies that effectively achieve these aims by promoting and sustaining activity, independence and health in old age (European Commission, 2018).

Education is seen as one way of promoting active ageing, because learning in later life helps develop social contacts and postpones cognitive problems associated with getting older (Phillipson and Ogg, 2010; Santos et al., 2014; Gitto, 2018). Consistent with this perspective, Universities of the Third Age (UTAs) have been established in many industrialized countries (Formosa, 2014).

Universities of the Third Age are defined as sociocultural centers that provide elderly with adult learning and a range of activities associated with wellbeing in later life (Formosa, 2012; Swindell and Thomson, 1995). In Italy adult population can enroll in free informal courses and educational activities delivered by the UTAs. Noticeably successful have been courses and activities on Information and Communication Technologies (ICTs) (Mayhorn et al., 2004; Irizzarry, Downing and West, 2001), primarily because, up to now, people aged 65 years or older are not very familiar with them. Through the use of ICT people can surf the internet, use electronic mail and keep in touch with their relatives, log in to institutional websites to get access to public services, buy electronic tickets for leisure time. All these activities support the integration of the ageing population within society and increase its active participation to social life. The use of ICT also reduces the burden of many administrative tasks, thereby enabling older adults to manage their bank accounts, bill payments, etc., directly from home, without the need for external help. This benefit from the use of ICTs is crucial for older people with physical activity limitations; it reduces loneliness and isolation while increasing self-confidence and enabling them to access services more inexpensively (Heyn Billip, 2001). 
The paper focuses on a sample of 341 elderly people attending UTA courses in Milazzo, an Italian town situated in Southern Italy; the specific name of the University is Libera Università della Terza Età (LUTE). Through the application of different model specifications, I analyze the impact of ICT use on elderly's quality of life. Literature reports evidence of a positive effect of ICT use on the wellbeing of older population, which is often measured in terms of "social relations", "increased autonomy" and "life enhancement" (Phillipson and Ogg, 2010, Gonzalez, Ramirez and Viadel, 2012), but very few studies use parameters able to specifically assess the quality of life. This study thus contributes to the extant literature by using a detailed and comprehensive measure of QoL, the WHOQol-Bref, which is an instrument validated by the World Health Organization aimed at assessing individuals' quality of life through a questionnaire representing different aspects of everyday life. Results corroborate the extant literature's findings on the positive impact of ICT use on elderly wellbeing and this evidence suggests valuable policy considerations.

\section{Older Adults and Information and Community Technology Use}

In recent years, there has been a growing interest among scholars on ICT use and their beneficial effects on ageing population. Almost all contributions support the positive impact of ICT on the older population through enhancements to their social participation and psychosocial wellbeing (Heart and Kalderon, 2013; Hernández-Encuentra, Pousada and Gómez-Zúñiga, 2009). Several sources suggest that the main beneficial effect is represented by stronger relationships with friends and family, which leads to a higher level of social engagement (Age UK, 2010). Additionally, using computers and surfing the internet gives older people a greater sense of independence (Morris, Goodman and Brading, 2007), especially for those who are housebound and may feel isolated. People who are constant internet users tend to report higher autonomy in various aspects of their lives (Mason, Sinclair and Berry, 2012). Similarly, older people who own a mobile phone are more likely to experience a sense of freedom and independence (Martinez-Pecino et al., 2012); they feel safer in cases of emergencies as well (Nguyen et al., 2015).

It is unquestionable that technology pervades every aspect of modern life and ICT tools have the potential for improving the QoL of older adults in many aspects of their lives, especially if applied to areas which are strategic for their wellbeing, such as housing, health and social services (Siren and Gronborg Knudsen, 2017, Heart and Kalderon, 2013). Telemedicine, for example, has increasingly allowed older people to stay home and be monitored via ICT applications by a doctor or a medical center rather than experience placement in a hospital or rehabilitation facility (Vimarlund and Olve, 2015). However, even in industrialized countries, access to ICT by older population is not as straightforward as it may be for younger adults. A growing strand of literature suggests that older adults are physically and psychologically disadvantaged when using new technologies. They are less self-confident and more selective than younger people when using ICT (Broady, Chan and Caputi, 2010; Rosseau and Rogers, 1998). They are also more likely to experience physical limitations such as a sight decrement and hand-eye coordination and motor functioning difficulties which represent obstacles to using ICT (Selwyn, Gorard and Furlong, 2003). Factors such as previous computer experience, computer anxiety, and perceived usefulness may influence the development of older adults' attitudes towards computers.

There are, of course, specific variables that impact on the familiarity with ICT use by older people, and these are mostly related to the socioeconomic status. A Canadian study, for example, showed that higher socioeconomic status in childhood, as measured using parents' education and family income, impacts positively on internet use by older adults, a relationship that emerges if an individual experienced at least one period of high socioeconomic status in later in life as well (Pannor Silver, 2013). There are also material factors related to the socioeconomic divide in using internet and ICTs. The majority of elderly people do not have their own computers, because they cannot afford them. Health, as well, is a determinant in the use of computers, with healthier elderly more prone to make use of ICT compared to their less healthy counterparts (Heart and Kalderon 2013).

\section{Methods}

The study was carried out as part of a larger project aimed at assessing the QoL of individuals enrolled at the LUTE in Milazzo, Sicily (Italy). The LUTE was established in 2011 and adheres to the AUSER, the Italian association that promotes active ageing. It operates in the field of lifelong learning and teachers are volunteers. Courses are free, although students need to register in order to attend the lectures and to join the organized activities. In 2016, the year when the survey was carried out, individuals attending the courses, teaching or working as volunteers at LUTE were almost nine hundred.

There are more than one hundred courses and they cover different thematic areas, such as Literature, Medicine, Human Science and Computer Technology. About the latter, there are specific laboratories aimed at making individuals familiar with the use of ICT, as personal computer, tablet and smartphone. 


\section{Data}

The sample has been taken from people enrolled at the LUTE during the academic year 2015/2016. On April 6, 2016 a questionnaire was distributed to people attending courses who had volunteered to complete the survey. Oral, written and on line communication on the forthcoming survey was previously circulated among LUTE's participants to recruit respondents to the survey. The time required to complete the questionnaire was about 30 minutes; personnel were available onsite to provide clarification if needed.

Questionnaire's items addressed four main domains:

i. Individual socioeconomic characteristics, namely age, gender, place of residence, marital status, educational level, job, living arrangements;

ii. Involvement with LUTE, with questions addressing the weekly hours spent for classes, the number of courses, main topics covered, role played within LUTE (teacher, student or volunteer), number of years involved in LUTE's activities, reasons for attending LUTE's activities, practical information on courses' setting (e.g. the presence of laboratory), previous expectations and degree of satisfaction with LUTE's activities, the pros and cons of LUTE, distance from LUTE, and travel information;

iii. Current use of ICT, namely the kind of ICT used, internet availability at home, frequency and place of use; Quality of life, which was assessed through the use of WHOQoL Bref, composed of 24 items, related to specific dimensions of everyday life, plus 2 separate items aimed at asking the respondents to directly rate, on a 0-5 Likert scale, their health status and QoL.

Overall, 341 people out of 380 enrolled at the ICT laboratories answered the items of the questionnaire, showing a very high response rate. However, since the final calculation of the WHOQoL Bref requires each of the items to be fulfilled, I could include in the sample only 250 observations, because only 250 respondents completed the entire form.

\section{Measures}

The aim of the paper consists in evaluating the impact of ICT use on elderly's quality of life. The dependent variable is a continuous variable, the WHOQoL Bref score, which is a parameter aimed at assessing the QoL of respondents. As shown in Table 1, it consists of 24 items related to different aspects of well-being, including physical health, psychological health, environmental health and social relationships, plus two separate items which provide further information about an individual's overall perception of his/her QoL (answer to the question "How would you rate your Quality of Life?") and the perception of his/her own health (answer to the question "How satisfied are you with your health?"). Each of the 26 items is rated on a 5-point Likert scale, where higher scores denote a higher QoL (WHOQoL Group, 1998; Skevington, Lotfy and O'Connell, 2004). The final score includes the WHOQoL total score for each of the four domains, and encompasses the two separate items' score as well. Details on the algorithms used to obtain the final score, which is comparable to the more widespread WHOQoL100 score, can be found elsewhere (WHO, 1996).

The primary independent variables relate to three different aspects of ICT use, namely the frequency of use, the place where individuals mainly use their ICT tools, and the kind of device used (personal computer (PC), tablet, or smartphone). Each aspect of ICT use is represented by four categorical variables. The three ICT measures are employed separately as the main regressors in three different models predicting WHOQoL Bref score.

For the frequency of use, respondents were asked how often a month they used an ICT tool. Answers could be: i) less than one hour a month; ii) once a week; iii) more than one hour a week; iv) every day. Four dummy variables were created for each of these categories with "every day" serving as the reference category in the first model specification.

With respect to the place where individuals mainly use their ICT tools, possible answers include: i) I use it almost never; ii) not at home, but elsewhere (e.g., at friends'/ relatives' homes, community centers); iii) at home; iv) when travelling. Four dummy variables were created for each of these categories with "never" serving as the reference category in the second model specification.

For kind of device used, the questionnaire provided four items related to this point (multiple choice was possible). The answers were: i) personal computer; ii) tablet; iii) smartphone, and iv) none. I employed as regressors the three former dummy variables and dropped the one indicating no use of ICT. As for controls, I created a vector containing the most common socioeconomic variables (age, education, marital status, income, living arrangements). I named the vector "socioec"and employed it in each model specification (Jones, 2007). The vector does not include information on job position because the different occupational categories were very scarcely represented (see table 1). For the same reason, with reference to income classes, I merged into a single category all the observations showing an income greater than 28,000 euro, which is the threshold under which the majority $(n=157)$ of the survey participants is concentrated. The two other income categories represented are "less than 15,000 euro" and "between 15,000 and 28,000 euro". With the exception of age, all the regressors are dummy variables. The "reference individual" is a woman, 60 years old, married, she holds a high school degree, with an income ranging from $€ 15,000$ to $€ 28,000$, and lives with her partner. 
Table 1 - Characteristics of the sample

\begin{tabular}{|c|c|c|c|c|c|}
\hline Variable & No. respondents & $\%$ & Std. dev. & Min & Max \\
\hline $\begin{array}{l}\text { ICT availability (multiple choice) } \\
\text { Personal computer } \\
\text { Tablet } \\
\text { Smartphone } \\
\text { None }\end{array}$ & $\begin{array}{l}\mathbf{2 5 0} \\
172 \\
58 \\
118 \\
20 \\
\end{array}$ & $\begin{array}{l}0.688 \\
0.232 \\
0.472 \\
0.08 \\
\end{array}$ & $\begin{array}{l}0.464 \\
0.423 \\
0.500 \\
0.271 \\
\end{array}$ & $\begin{array}{l}0 \\
0 \\
0 \\
0\end{array}$ & $\begin{array}{l}1 \\
1 \\
1 \\
1\end{array}$ \\
\hline $\begin{array}{l}\text { Ability in using ICT (multiple choice) } \\
\text { I cannot do anything } \\
\text { Text messages } \\
\text { Surfing the net } \\
\text { Social network }\end{array}$ & $\begin{array}{l}250 \\
30 \\
119 \\
182 \\
116 \\
\end{array}$ & $\begin{array}{l}0.120 \\
0.476 \\
0.728 \\
0.464 \\
\end{array}$ & $\begin{array}{l}0.326 \\
0.500 \\
0.446 \\
0.500 \\
\end{array}$ & $\begin{array}{l}0 \\
0 \\
0 \\
0\end{array}$ & $\begin{array}{l}1 \\
1 \\
1 \\
1\end{array}$ \\
\hline $\begin{array}{l}\text { Where do you use ICT? } \\
\text { Wherever } \\
\text { At friends' } \\
\text { At home } \\
\text { When travelling/moving }\end{array}$ & $\begin{array}{l}250 \\
15 \\
6 \\
199 \\
82 \\
\end{array}$ & $\begin{array}{l}0.064 \\
0.024 \\
0.796 \\
0.328 \\
\end{array}$ & $\begin{array}{l}0.245 \\
0.153 \\
0.404 \\
0.470 \\
\end{array}$ & $\begin{array}{l}0 \\
0 \\
0 \\
0\end{array}$ & $\begin{array}{l}1 \\
1 \\
1 \\
1\end{array}$ \\
\hline $\begin{array}{l}\text { Access to internet } \\
\text { Internet yes } \\
\text { Internet no } \\
\text { Internet do not know }\end{array}$ & $\begin{array}{l}\mathbf{2 5 0} \\
220 \\
23 \\
7\end{array}$ & $\begin{array}{l}0.880 \\
0.09 \\
0.03 \\
\end{array}$ & $\begin{array}{l}.326 \\
.290 \\
.090 \\
\end{array}$ & $\begin{array}{l}0 \\
0 \\
0 \\
\end{array}$ & $\begin{array}{l}1 \\
1 \\
1 \\
\end{array}$ \\
\hline Age & 244 & 62.42 (mean) & 10.769 & 27 & 95 \\
\hline $\begin{array}{l}\text { Living arrangements: } \\
\text { Alone } \\
\text { Partner } \\
\text { Family }\end{array}$ & $\begin{array}{l}\mathbf{2 5 0} \\
37 \\
118 \\
100 \\
\end{array}$ & $\begin{array}{l}0.148 \\
0.464 \\
0.400 \\
\end{array}$ & $\begin{array}{l}0.356 \\
0.500 \\
0.491 \\
\end{array}$ & $\begin{array}{l}0 \\
0 \\
0\end{array}$ & $\begin{array}{l}1 \\
1 \\
1\end{array}$ \\
\hline $\begin{array}{l}\text { Education: } \\
\text { Compulsory education } \\
\text { High school } \\
\text { Academic }\end{array}$ & $\begin{array}{l}250 \\
52 \\
100 \\
48 \\
\end{array}$ & $\begin{array}{l}0.208 \\
0.604 \\
0.192 \\
\end{array}$ & $\begin{array}{l}0.407 \\
0.490 \\
0.394 \\
\end{array}$ & $\begin{array}{l}0 \\
0 \\
0 \\
\end{array}$ & $\begin{array}{l}1 \\
1 \\
1 \\
\end{array}$ \\
\hline $\begin{array}{l}\text { Activity: } \\
\text { Pensioner } \\
\text { Self-employee } \\
\text { Teacher } \\
\text { Salesman } \\
\text { Employee } \\
\text { Housewife } \\
\text { Unemployed }\end{array}$ & $\begin{array}{l}250 \\
136 \\
8 \\
13 \\
4 \\
23 \\
63 \\
17 \\
\end{array}$ & $\begin{array}{l}0.544 \\
0.032 \\
0.052 \\
0.016 \\
0.092 \\
0.252 \\
0.068 \\
\end{array}$ & $\begin{array}{l}0.499 \\
0.176 \\
0.222 \\
0.126 \\
0.290 \\
0.435 \\
0.252 \\
\end{array}$ & $\begin{array}{l}0 \\
0 \\
0 \\
0 \\
0 \\
0 \\
0\end{array}$ & $\begin{array}{l}1 \\
1 \\
1 \\
1 \\
1 \\
1 \\
1\end{array}$ \\
\hline $\begin{array}{l}\text { Income: } \\
<15,000 € \\
15,000-28,000 € \\
28,001-55,000 € \\
55,001-75,000 € \\
>75,000 € \\
\text { No answer }\end{array}$ & $\begin{array}{l}\mathbf{2 3 3} \\
78 \\
79 \\
26 \\
5 \\
1 \\
44 \\
\end{array}$ & $\begin{array}{l}0.281 \\
0.290 \\
0.097 \\
0.015 \\
0.003 \\
0.183\end{array}$ & $\begin{array}{l}0.450 \\
0.454 \\
0.296 \\
0.120 \\
0.054 \\
0.386\end{array}$ & $\begin{array}{l}0 \\
0 \\
0 \\
0 \\
0 \\
0\end{array}$ & $\begin{array}{l}1 \\
1 \\
1 \\
1 \\
1 \\
1 \\
1\end{array}$ \\
\hline
\end{tabular}




\section{Model Specification}

Three ordinary least squares (OLS) regressions were run, each addressing a distinctive aspect of ICT use (frequency, place and kind of device used). Since I was especially interested in observing the use of ICT among the elderly, I tested each regression on both the whole sample $(\mathrm{n}=250)$ and a restricted sample, including only people over 65 years old $(\mathrm{n}$ $=119$ ).

The relatively low number of observations in the sample, and especially in the subsample, was the main reason for choosing to keep the regressors related to the three different features separate. The second reason relates to multicollinearity: after building a covariance matrix between the regressors related to each aspect of ICT use, I found out that some items were highly correlated (with a correlation index $\geq 0.5$ ) and it was therefore preferable to use them in different model specifications. Finally, investigating each aspect separately allows for a clearer delineation of the relationship between each measure of ICT use and the dependent variable and addresses a clearer analysis of policy implications.

Given the standard OLS equation:

$$
y_{i}=\alpha+\beta x_{i}+\varepsilon
$$

the three model specifications described above were run on both the whole sample and the restricted sample.

\section{Results}

\section{a) Descriptive statistics}

Table 1 reports the characteristics of the sample of people who answered the survey and the scores reported in the WHOQoL Bref questionnaire. The participants to the survey were 62 years old on average: the age in the sample ranges from 27 to 95 years, although the distribution is skipped to the right (almost 50\% of the people in the sample were over 65 years old), which is not surprising since the courses are mainly attended by older people.

Two thirds of the respondents were female; $71.6 \%$ were married and $86.4 \%$ lived with the family or with the partner; only $14.8 \%$ declared to live alone.

More than sixty per cent of the participants completed high school, $19.2 \%$ had an academic education. This educational framework suggests that there might be self-selection in the decision to attend LUTE's courses and this evidence should be considered when addressing policy measures.

Most of respondents are retired $(n=136)$ and $25 \%$ of the sample is represented by housewives; professional figures such as salesmen or employees are almost not represented.

There are two levels of income more represented, respectively less than $€ 15,000$ (28\%) and between 15,000 and 28,000 Euro (29\%); $18 \%$ of respondents gave no answer to this topic.

The majority of respondents $(88 \%)$ have an internet connection at home and use, therefore, ICT frequently/very frequently $(77.2 \%)$. Home is the preferred site to use ICT (79.6\% of the respondents); however, almost one third of the respondents uses these technologies when travelling/moving.

Tablets are the least popular devices (23.2\%, comparing to smartphone - $47.2 \%$ - and personal computer - $68.8 \%)$. Most people in the sample use ICT to surf the internet (72.8\%), $46.4 \%$ use social networks, but there still remains a $12 \%$ that cannot use ICT. This percentage increases to $18 \%$ for the restricted sample.

With reference to the QoL, the value of the WHOQOL-Bref, referred to the whole sample, ranges from 51 to 120, with a mean of 90.4. Since domain scores are scaled in a positive direction, higher values of WHQOL-Bref denote a higher QoL.

\section{b) Main results}

Results from all the regressions clearly address a positive impact of ICT use on the respondents' QoL. Starting from the frequency of ICT use by LUTE's attendants, table 2 shows that the categorical variables addressing a very scarce use of ICT (less than one hour a month) is both negative and highly significant $(\mathrm{p}<0.01)$. Using an ICT device very few times compared to using it every day has a negative impact on the quality of life and can decrease the total WHOQoL-Bref score by 6.7 points. If we look at the restricted sample (people over 65), results are even stronger: both the variables addressing less than one hour a month and once a week are negative and highly significant, which means that an elderly who uses a smartphone, a tablet and/or a PC once a week or even less, has a greater probability of experimenting a lower QoL with respect to an over 65 individual (having the same socioeconomic characteristics) who uses these technologies very often. The magnitude of the effect on the final WHOQOL-Bref score is also higher, with effects of, respectively, 8 and 12 points. 
Controls confirm evidence from literature: having just compulsory education compared to holding a high school degree impacts negatively on the QoL (Grossman, 2000) and the significance of this regressor is kept through both specifications; for marital status, being single compared to being married impacts negatively on the QoL (Averett et al. 2013), but this result is significant only for the regressions run on the whole sample ( $<<0.1)$, possibly because this figure is almost entirely unrepresented in the subsample $(n=8)$. The same negative impact is due to the circumstance of being a widower, with the level of significance varying according to the sample represented. Keeping the reference income between 15,000 and 28,000, a lower income (less than 15,000) has a negative impact on the QoL, whilst a higher income (more than 28,000) impacts positively.

Table 2 -Impact of ICT frequency of use on the individual QoL

\begin{tabular}{|c|c|c|c|}
\hline Variables & $\begin{array}{c}\text { whole sample } \\
\text { (std. errors in brackets): }\end{array}$ & $\begin{array}{c}\text { over } 65 \\
\text { (std. errors in brackets): }\end{array}$ & $\begin{array}{c}\text { aged } 65 \text { or less } \\
\text { (std. errors in brackets): }\end{array}$ \\
\hline $\begin{array}{l}\text { When using ICT: } \\
\text { Less than one hour a month } \\
\text { Once a week } \\
\text { More than one hour a week } \\
\text { Every day (omitted) }\end{array}$ & $\begin{array}{c}-6.700 * * * \\
(2.499) \\
-4.192 \\
(2.832) \\
-2.506 \\
(2.097) \\
-\end{array}$ & $\begin{array}{c}-8.502 * * * \\
(2.844) \\
-12.487 * * * \\
(3.755) \\
-2.148 \\
(2.583) \\
-\end{array}$ & $\begin{array}{c}-3.850 \\
(4.84) \\
2.834 \\
(4.58) \\
-4.890 \\
(3.520) \\
-\end{array}$ \\
\hline Age & $\begin{array}{l}-0.157 * \\
(0.089)\end{array}$ & $\begin{array}{l}-0.326 \\
(0.214)\end{array}$ & $\begin{array}{c}0.047 \\
(0.192)\end{array}$ \\
\hline Gender (male) & $\begin{array}{l}-0.046 \\
(1.675) \\
\end{array}$ & $\begin{array}{l}1.980 \\
(2.338) \\
\end{array}$ & $\begin{array}{c}2.163 \\
(2.810) \\
\end{array}$ \\
\hline $\begin{array}{l}\text { Living: } \\
\text { Alone } \\
\text { Family } \\
\text { With partner (omitted) }\end{array}$ & $\begin{array}{c}4.547 \\
(3.097) \\
-1.533 \\
(1.751) \\
-\end{array}$ & $\begin{array}{c}4.356 \\
(3.982) \\
-3.198 \\
(2.474) \\
-\end{array}$ & $\begin{array}{c}2.462 \\
(5.244) \\
-0.070 \\
(2.661) \\
-\end{array}$ \\
\hline $\begin{array}{l}\text { Education: } \\
\text { Compulsory } \\
\text { Graduate } \\
\text { High school (omitted) }\end{array}$ & $\begin{array}{c}-4.752 * * \\
(1.997) \\
-0.202 \\
(2.001) \\
-\end{array}$ & $\begin{array}{c}-7.250 * * * \\
(2.551) \\
2.690 \\
(2.802) \\
-\end{array}$ & $\begin{array}{c}-2.946 \\
(3.067) \\
-1.306 \\
(3.095) \\
-\end{array}$ \\
\hline $\begin{array}{l}\text { Marital status: } \\
\text { Single } \\
\text { Divorced } \\
\text { Widowed } \\
\text { Married (omitted) }\end{array}$ & $\begin{array}{c}-6.703 * * \\
(3.060) \\
-2.563 \\
(3.259) \\
-6.845 * * \\
(3.195) \\
-\end{array}$ & $\begin{array}{c}-5.281 \\
(4.899) \\
-3.603 \\
(4.272) \\
-6.653 * \\
(3.968) \\
-\end{array}$ & $\begin{array}{c}-5.568 \\
(4.732) \\
0.615 \\
(5.217) \\
-1.777 \\
(5.934) \\
-\end{array}$ \\
\hline $\begin{array}{l}\text { Income: } \\
\text { Less } 15,000 € \\
\text { More } 28,000 € \\
\text { No answer } \\
15,000-28,000 € \text { (omitted) }\end{array}$ & $\begin{array}{c}-4.880 * * * \\
(1.810) \\
6.432 * * * \\
(2.452) \\
-1.679 \\
(2.260) \\
-\end{array}$ & $\begin{array}{c}-3.975^{*} \\
(2.380) \\
4.236 \\
(2.823) \\
1.992 \\
(3.273) \\
-\end{array}$ & $\begin{array}{c}-5.023 * \\
(2.824) \\
6.935 \\
(4.413) \\
-2.595 \\
(3.338) \\
-\end{array}$ \\
\hline Constant & $\begin{array}{c}105.245^{* * *} \\
(5.798) \\
\mathrm{R}^{2}=0.237 \\
\text { Adj. } \mathrm{R}^{2}=0.187 \\
\mathrm{~F}(15,228)=4.73 \\
\text { Prob> } \mathrm{F}=0.000 \\
\text { Number obs. }=244\end{array}$ & $\begin{array}{c}116.893 * * * \\
(14.880) \\
\mathrm{R}^{2}=0.417 \\
\text { Adj. } \mathrm{R}^{2}=0.332 \\
\mathrm{~F}(15,103)=4.91 \\
\text { Prob> } \mathrm{F}=0.000 \\
\text { Number obs. }=119\end{array}$ & $\begin{array}{c}92.64 * * * \\
(11.443) \\
\mathrm{R}^{2}=0.173 \\
\text { Adj. } \mathrm{R}^{2}=0.060 \\
\mathrm{~F}(15,109)=1.52 \\
\text { Prob> } \mathrm{F}=0.109 \\
\text { Number obs. }=125\end{array}$ \\
\hline
\end{tabular}


Table 3 -Impact of ICT place of use on the individual QoL

\begin{tabular}{|c|c|c|c|}
\hline Variables & $\begin{array}{c}\text { whole sample } \\
\text { (std. errors in brackets): }\end{array}$ & $\begin{array}{c}\text { over } 65 \\
\text { (std. errors in brackets): }\end{array}$ & $\begin{array}{c}\text { aged } 65 \text { or less } \\
\text { (std. errors in brackets): }\end{array}$ \\
\hline \multicolumn{4}{|l|}{ Where using ICT: } \\
\hline Not at home & $\begin{array}{c}5.358 \\
(4.787)\end{array}$ & $\begin{array}{l}-0.013 \\
(7.915)\end{array}$ & $\begin{array}{l}3.725 \\
(6.767)\end{array}$ \\
\hline My home & $3.940 * *$ & $5.588 * *$ & -.6298 \\
\hline & $(1.969)$ & $(2.407)$ & $(3.527)$ \\
\hline Eventravelling & $5.052 * * *$ & $9.245 * * *$ & 2.559 \\
\hline (1) & $(1.812)$ & $(2.560)$ & $(2.698)$ \\
\hline Almost never (omitted) & - & - & - \\
\hline Age & $\begin{array}{l}-0.124 \\
(0.092)\end{array}$ & $\begin{array}{l}-0.026 \\
(0.217)\end{array}$ & $\begin{array}{c}0.063 \\
(0.201)\end{array}$ \\
\hline Gender (male) & $\begin{array}{l}-0.716 \\
(1.652)\end{array}$ & $\begin{array}{l}-0.334 \\
(2.257)\end{array}$ & $\begin{array}{l}1.264 \\
(2.743)\end{array}$ \\
\hline \multicolumn{4}{|l|}{ Living: } \\
\hline Alone & $\begin{array}{l}5.115^{*} \\
(3.095)\end{array}$ & $\begin{array}{c}5.341 \\
(3.994)\end{array}$ & $\begin{array}{c}4.354 \\
(5.349)\end{array}$ \\
\hline Family & $\begin{array}{l}-1.479 \\
(1.737)\end{array}$ & $\begin{array}{l}-2.204 \\
(2.411)\end{array}$ & $\begin{array}{l}0.382 \\
(2.735)\end{array}$ \\
\hline With partner (omitted) & - & - & $\begin{array}{c}- \\
(2.100) \\
-\end{array}$ \\
\hline \multicolumn{4}{|l|}{ Education: } \\
\hline Compulsory & $\begin{array}{c}-4.648 * * \\
(1.993)\end{array}$ & $\begin{array}{c}-8.116^{* * * *} \\
(2.493)\end{array}$ & $\begin{array}{l}-2.509 \\
(3.233)\end{array}$ \\
\hline Graduate & -1.396 & -0.877 & -1.322 \\
\hline High school (omitted) & $\begin{array}{c}(1.997) \\
-\end{array}$ & $\begin{array}{c}(2.730) \\
-\end{array}$ & $\begin{array}{c}(3.0975) \\
-\end{array}$ \\
\hline \multicolumn{4}{|l|}{ Marital status: } \\
\hline Single & $\begin{array}{c}-6.925 * * \\
(3.031)\end{array}$ & $\begin{array}{l}-5.490 \\
(4.866)\end{array}$ & $\begin{array}{l}-6.233 \\
(4.743)\end{array}$ \\
\hline Divorced & $\begin{array}{l}-2.506 \\
(3.342)\end{array}$ & $\begin{array}{l}-4.984 \\
(4.295)\end{array}$ & $\begin{array}{l}-1.776 \\
(5.562)\end{array}$ \\
\hline Widowed & $-6.666^{* *}$ & $-7.688^{*}$ & -3.040 \\
\hline Married (omitted) & $\begin{array}{c}(3.094) \\
-\end{array}$ & $\begin{array}{c}(3.920) \\
-\end{array}$ & $\begin{array}{c}(5.149) \\
-\end{array}$ \\
\hline \multicolumn{4}{|l|}{ Income: } \\
\hline Less $15,000 €$ & $\begin{array}{c}-3.832 * * \\
(1.841)\end{array}$ & $\begin{array}{l}-1.830 \\
(2.524)\end{array}$ & $\begin{array}{l}-5.121 * \\
(2.837)\end{array}$ \\
\hline \multirow[t]{2}{*}{ More $28,000 €$} & $7,185^{* * *}$ & $6.380^{* *}$ & 6.276 \\
\hline & $(2.418)$ & $(2.744)$ & $(4.550)$ \\
\hline \multirow[t]{2}{*}{ No answer } & -1.556 & 0.903 & -3.402 \\
\hline & $(2.251)$ & $(3.191)$ & $(3.365)$ \\
\hline $15,000-28,000 €($ omitted) & - & - & - \\
\hline \multirow[t]{2}{*}{ Constant } & $\begin{array}{c}96.555 * * * \\
(6.866)\end{array}$ & $\begin{array}{c}104.094 * * * \\
(15.859)\end{array}$ & $\begin{array}{l}90.601 * * * \\
(12.713)\end{array}$ \\
\hline & $\begin{array}{c}\mathrm{R}^{2}=0.245 \\
\text { Adj. } \mathrm{R}^{2}=0.196 \\
\mathrm{~F}(15,228)=4.94 \\
\text { Prob> } \mathrm{F}=0.000 \\
\text { Number obs. }=244\end{array}$ & $\begin{array}{c}\mathrm{R}^{2}=0.423 \\
\text { Adj. } \mathrm{R}^{2}=0.339 \\
\mathrm{~F}(15,103)=5.04 \\
\text { Prob> } \mathrm{F}=0.000 \\
\text { Number obs. }=119\end{array}$ & $\begin{array}{c}\mathrm{R}^{2}=0.160 \\
\text { Adj. } \mathrm{R}^{2}=0.044 \\
\mathrm{~F}(15,109)=1.38 \\
\text { Prob> } \mathrm{F}=0.170 \\
\text { Number obs. }=125\end{array}$ \\
\hline
\end{tabular}

Results of the second model specification deal with the place of use and are reported in table 3. As might be expected, using ICT at home impacts positively on QoL ( $<<0.5$ in both regressions, run on the whole and restricted sample). It is however surprising to find out that using these tools when travelling has a positive and significant impact on the elderly's QoL. It has been shown that using an ICT when travelling is a very common and enjoyable practice among young people, who like surfing the internet and/or chatting with friends (Konrad and Wittowsky, 2017). Further, this habit increases the productivity for workers who employ their travel time in functional activities, but it is quite surprising to find out that LUTE's attendants (whole sample) have a positive return from the use of ICT when travelling and even more surprising to detect a positive and significant impact of this variable in the regression run on the restricted sample: people aged 65 and over benefit from using an ICT tool when travelling and the effect on the final WHOQoL-Bref score is higher (9.245 points) comparing to the whole sample. Controls maintain almost all the sign and level of significance reported in the previous regression, corroborating the empirical exercise. 
Finally, with the third regression I tested whether the use of a specific ICT (either a PC, a tablet or a smartphone) could impact on respondents' QoL. In both equations, run respectively on the whole and the restricted sample, a positive impact on QoL due to the use of a PC is detected ( $\mathrm{p}<0.01$ ), whilst no significant effects are identified for the use of either a tablet or a smartphone. This aspect is rather uninvestigated by literature and deserves a deeper insight.

Table 4 - Impact of the kind of ICT used on the individual QoL

\begin{tabular}{|c|c|c|c|}
\hline Variables & $\begin{array}{l}\mathbf{1}^{\text {st }} \text { model - whole sample } \\
\text { (std. errors in brackets): }\end{array}$ & $\begin{array}{c}2^{\text {nd }} \text { model - over } 65 \\
\text { (std. errors in brackets): }\end{array}$ & $\begin{array}{c}\text { aged } 65 \text { or less } \\
\text { (std. errors in brackets): }\end{array}$ \\
\hline $\begin{array}{l}\text { Which ICT device: } \\
\text { PC } \\
\text { Tablet } \\
\text { Smartph } \\
\text { No tools (omitted) }\end{array}$ & $\begin{array}{c}5.041 * * * \\
(1.683) \\
0.044 \\
(1.740) \\
-0.620 \\
(1.580) \\
-\end{array}$ & $\begin{array}{c}6.451 * * * \\
(2.203) \\
3.645 \\
(2.341) \\
-2.501 \\
(2.152) \\
-\end{array}$ & $\begin{array}{c}2.127 \\
(2.748) \\
-2.868 \\
(2.697) \\
1.070 \\
(2.497) \\
-\end{array}$ \\
\hline Age & $\begin{array}{c}-0.231 * * * \\
(0.088)\end{array}$ & $\begin{array}{l}-0.390^{*} \\
(0.224)\end{array}$ & $\begin{array}{c}0.035 \\
(0.190)\end{array}$ \\
\hline Gender (male) & $\begin{array}{l}-1.003 \\
(1.679) \\
\end{array}$ & $\begin{array}{l}-1.191 \\
(2.328) \\
\end{array}$ & $\begin{array}{c}1.572 \\
(2.810)\end{array}$ \\
\hline $\begin{array}{l}\text { Living: } \\
\text { Alone } \\
\text { Family } \\
\text { With partner (omitted) }\end{array}$ & $\begin{array}{c}4.856 \\
(3.093) \\
-1.951 \\
(1.744) \\
-\end{array}$ & $\begin{array}{c}6.904 * \\
(4.109) \\
-2.047 \\
(2.461) \\
-\end{array}$ & $\begin{array}{c}2.872 \\
(5.208) \\
-0.048 \\
(2.683) \\
-\end{array}$ \\
\hline $\begin{array}{l}\text { Education: } \\
\text { Compulsory } \\
\text { Graduate } \\
\text { High school (omitted) }\end{array}$ & $\begin{array}{c}-4.876 * * \\
(2.002) \\
-1.370 \\
(2.010) \\
- \\
\end{array}$ & $\begin{array}{c}-6.823 * * \\
(2.634) \\
-0.839 \\
(2.779) \\
-\end{array}$ & $\begin{array}{c}-2.782 \\
(3.130) \\
-1.479 \\
(3.086) \\
-\end{array}$ \\
\hline $\begin{array}{l}\text { Marital status: } \\
\text { Single } \\
\text { Divorced } \\
\text { Widowed } \\
\text { Married (omitted) }\end{array}$ & $\begin{array}{c}-8.059 \\
(3.066) \\
-1.390 \\
(3.292) \\
-5.998 * * \\
(3.105) \\
-\end{array}$ & $\begin{array}{c}-7.107 \\
(4.972) \\
-4.297 \\
(4.337) \\
-7.842 * \\
(4.036) \\
-\end{array}$ & $\begin{array}{c}-4.830 \\
(4.638) \\
1.119 \\
(5.432) \\
-2.756 \\
(5.802) \\
-\end{array}$ \\
\hline $\begin{array}{l}\text { Income: } \\
\text { Less } 15,000 € \\
\text { More } 28,000 € \\
\text { No answer } \\
15,000-28,000 €(\text { omitted) }\end{array}$ & $\begin{array}{c}-4.541 * * \\
(1.806) \\
7.335 * * * \\
(2.431) \\
-2.108 \\
(2.243) \\
-\end{array}$ & $\begin{array}{c}-4.219 * \\
(2.425) \\
6.650 * * \\
(2.814) \\
-2.206 \\
(3.223) \\
-\end{array}$ & $\begin{array}{c}-4.977 * \\
(2.857) \\
6.246 \\
(4.492) \\
-3.067 \\
(3.422) \\
-\end{array}$ \\
\hline Constant & $\begin{array}{c}105.641^{* * *} \\
(6.308) \\
\mathrm{R}^{2}=0.240 \\
\text { Adj. } \mathrm{R}^{2}=0.190 \\
\mathrm{~F}(15,228)=4.79 \\
\text { Prob }>\mathrm{F}=0.000 \\
\text { Number obs. }=244\end{array}$ & $\begin{array}{c}115.651 * * * \\
(16.280) \\
\mathrm{R}^{2}=0.398 \\
\text { Adj. } \mathrm{R}^{2}=0.310 \\
\mathrm{~F}(15,103)=4.54 \\
\text { Prob }>\mathrm{F}=0.000 \\
\text { Number obs. }=119\end{array}$ & $\begin{array}{c}91.268 * * * \\
(11.861) \\
\mathrm{R}^{2}=0.167 \\
\text { Adj. } \mathrm{R}^{2}=0.52 \\
\mathrm{~F}(15,109)=1.46 \\
\text { Prob }>\mathrm{F}=1.350 \\
\text { Number obs. }=125\end{array}$ \\
\hline
\end{tabular}

To further corroborate the empirical exercise, I ran the three regressions on the subsample of people aged less than 65 years. Results show that for the "younger" LUTE's attendants neither the frequency of use nor the kind of ICT or the place of use have an impact on the outcome variable. This finding is remarkable, as it suggests that the positive impact of ICT use is clearly detected for the older population, whilst it is not possible to identify it for younger adults.

\section{c) Robustness check}


The robustness check was carried out through the specification of a probit model testing for the probability of experimenting good health, given a set of regressors on the frequency of ICT use.

As might be recalled, theWHQOL-Bref includes two separate items addressing respectively the individual's perception of both health and QoL. With reference to the former, possible answers to the question "How satisfied are you with your health?" are rated in an ascendant 5 points Likert scale from very unsatisfied to very satisfied; table 5 reports the distribution of this categorical variable. Since only one respondent chose "very unsatisfied", I dropped this observation in order to create a balanced dependent binary variable named "goodhealth", which takes the value of 1 if the individual is either very satisfied or satisfied with his/her health status and equals 0 if the individual is unsatisfied or neither unsatisfied nor satisfied with his/her health status (Jones, 2007).

Table 5 - Distribution of the score related to health status

\begin{tabular}{|ccc|}
\hline Score & Definition & $N(250)$ \\
\hline $\mathbf{1}$ & Very unsatisfied & 1 \\
$\mathbf{2}$ & Unsatisfied & 38 \\
$\mathbf{3}$ & Neither unsatisfied nor satisfied & 80 \\
$\mathbf{4}$ & Satisfied & 113 \\
$\mathbf{5}$ & Very satisfied & 18 \\
\hline
\end{tabular}

So, in my specification, the distribution of the dependent variable $\mathrm{Y}$ is the following:

$$
\mathrm{y}_{\mathrm{i}}= \begin{cases}1 & \text { if people are very satisfied } \text { and satisfied } \text { with their health status } \\ 0 & \text { if people are unsatisfied } \text { or neither unsatisfied nor satisfied with their health status. }\end{cases}
$$

In the final specification, $\mathrm{P}(\mathrm{Y}=1 \mid \mathrm{X})$ is the probability of scoring goodhealth and the three regressors chosen for the frequency of use are those addressing respectively less than one hour a month, once a week, more than one hour a week (the omitted variable refers to using ICT every day). I tested the probability of scoring goodhealth, given ICT frequency of use and controlling for a set of socioeconomic variables.

The estimated equation is:

$$
\mathrm{Y}=\beta \mathrm{X}+\varepsilon
$$

Results are reported in table 6 and support the previous findings. Specifically, using an ICT tool less than one hour a month compared to the circumstance of using it every day decreases the probability of scoring goodhealth $(\mathrm{p}<0.1)$ for both the whole and the restricted sample, with a bigger effect for the latter. Moreover, several controls that were significant in the OLS regressions, are significant in the probit model too and maintain the same sign. For example, with reference to the full sample, being single or widowed diminishes the probability of scoring goodhealth, compared to being married; having an income higher than $28,000 €$ (with a reference income between 15,000 and 28,000 ) increases the probability of scoring good health for both full and restricted sample, with a greater magnitude for the latter. All these findings prove the robustness of the model and the validity of the WHOQoL Bref as a parameter to assess the QoL.

Table 6 -Probability of scoring Good health given the frequency of ICT use

\begin{tabular}{|l|l|l|}
\hline Good health & $\begin{array}{l}\mathbf{1}^{\text {st }} \text { model - whole sample } \\
\text { (std. errors in brackets): }\end{array}$ & $\begin{array}{l}\mathbf{2}^{\text {nd }} \text { model - over 65 } \\
\text { (std. errors in brackets): }\end{array}$ \\
\hline When using ICT: & $-0.588^{*}(0.311)$ & $-0.751^{*}(0.441)$ \\
Less than one hour a month & $-0.535(0.351)$ & $-0.395(0.576)$ \\
Once a week & $-0.344(0.244)$ & $-0.130(0.346)$ \\
More than one hour a week & - & - \\
Every day (omitted vb.) & $-0.036^{* * *(0.011)}$ & $-0.058(0.036)$ \\
\hline Age & $-0.142(0.203)$ & $-0.285(0.336)$ \\
\hline Gender (male) & $0.190(0.381)$ & $0.559(0.645)$ \\
\hline Living: & $-0.334(0.211)$ & $-0.209(0.645)$ \\
Alone & - & - \\
Family & $-0.164(0.242)$ & $-0.190(0.366)$ \\
With partner (omitted) & $-0.192(0.242)$ & $0.419(0.401)$ \\
\hline Education: & - & - \\
Compulsory & $-0.958^{* *}(0.383)$ & $-0.961(0.829)$ \\
Graduate & & \\
High school (omitted) & Marital status: & \\
Single & & \\
\hline
\end{tabular}




\begin{tabular}{|l|l|l|}
\hline Divorced & $0.357 \quad(0.397)$ & $-0.278(0.621)$ \\
Widowed & $-0.277 * *(0.319)$ & $-0.688(0.656)$ \\
Married (omitted) & - & - \\
\hline Income: & $-0.330 \quad(0.217)$ & $-0.430 *(0.345)$ \\
Less $15,000 €$ & $0.974 * * *(0.316)$ & $1.146 * * *(0.411)$ \\
More $28,000 €$ & $0.012 \quad(0.270)$ & $-0.193 \quad(0.476)$ \\
No answer & - & - \\
$15,000-28,000 €($ omitted) & $2.739 * * *(0.727)$ & $4.346 * *(2.487)$ \\
\hline Constant & Number obs. $=244$ & Number obs. $=119$ \\
& LR chi2 $(15)=53.94$ & LR chi2 $(15)=35.70$ \\
& Prob $>$ chi2 $=0.0000$ & Prob $>$ chi2 $=0.0020$ \\
& pseudo $\mathrm{R}^{2}=0.1596$ & pseudo $\mathrm{R}^{2}=0.2224$ \\
\hline$* * *$ significant at 99\%; $* *$ significant at 95\%; $*$ significant at $90 \%$ & \\
\hline
\end{tabular}

\section{Discussion}

The whole empirical exercise is aimed at testing the positive impact of ICT use on elderly wellbeing. The results clearly indicate, through different model specifications and a robustness check, that the use of ICT impacts positively on the quality of life of LUTE's attendants. As highlighted in the Result section, this effect is detectable on the full sample and it is stronger for the restricted sample of people aged 65 and over, but it is not evident for the subsample of people with less than 65 years of age. This finding corroborates the awareness that ICT use is beneficial specifically for older population, who still have to exploit the many advantages of communication technologies, especially for the aspects related to social engagement, autonomy and leisure time; the same cannot be said for the youngest generations, who possibly have already internalized every advantage of ICT use.

Given this evidence, the challenge consists in helping older people familiarize themselves with ICT use. Considering that in the restricted sample of older people, $18 \%$ of participants answered that they cannot do anything with ICT, possible strategies consist in promoting teaching courses aimed at improving elderly's skills on ICT.

Another relevant issue relates to the variable employed to measure the elderly wellbeing. Up to now, the studies supporting the beneficial effect of ICT among older population utilized as dependent variables measures of social integration, personal self-esteem or individual autonomy. To our knowledge very few attempts have been made to employ parameters able to assess the quality of life of individuals. This study contributes to the extant literature by using a specific and comprehensive measure of QoL, the WHOQol-Bref, which is a rather complete parameter aimed at explaining different dimensions of everyday life. The three regressions and the robustness check show similar results and this evidence both validates the reliability of the WHOQol-Bref as an appropriate measure of QoL and the solidity of the empirical strategy. My suggestion is that parameters able to score the QoL of respondents will be employed in future works on this topic, in order to confirm the use of ICT as a possible strategy to maintain the ageing individuals healthy and active.

\section{Conclusions}

Ageing imposes to governments of developed countries one of the biggest economic and social challenge of this century. In order to contrast cognitive and physical impairment, the use of ICT among the elderly has been proven to exert a positive impact on their wellbeing.

The analysis carried out focuses on a sample of 341 people attending the LUTE, which is an educational organization addressing active ageing measures, and suggests that the use of ICT among them, and especially among people aged 65 and over, has a positive impact on their QoL.

Given this evidence, policy implications are twofold: first of all, any measure aimed at enabling ageing population in the use of ICT, as for example implementing courses that increase ICT skills, applying fiscal detractions in order to enhance the purchase of a PC by people in low socioeconomic conditions, and/or expanding free Wi-Fi zones, would increase the probability of favouring an active ageing process. The second point, although not specifically addressed by the model specification, deals with the positive effect of adult learning: given the evidence provided by literature on the importance of adult learning as a possible measure to keep psychological and social autonomy in older age, the present study indirectly confirms this position and suggests to promote the activities of UTA in Italy and in other developed countries. 


\section{References}

Averett, S. L., Argys, L. M., \& Sorkin, J. (2013). In sickness and in health: An examination of relationship status and health using data from the Canadian National Public Health Survey. Review Economics of the Household, 11(4), 599-633.

Age UK (2010) Technology and Older People: Evidence Review. Age UK, London. Available at: https://www.ageuk.org.uk/documents/en-gb/for-professionals/computers-and technology/evidence_review_technology.pdf?dtrk=true

Brenna, E. Di Novi, C. (2016). Is caring for older parents detrimental to women's mental health? The role of the European North-South gradient. Review of Economics of the Household, 14(4), 745-778. https://doi.org/10.1007/s11150-015-9296-7

Broady, T., Chan, A. \&Caputi, P., 2010. Comparison of older and younger adults' attitudestowards and abilities with computers: Implications for training and learning. British Journal of Education Technology, 41(3), 473-85.

European Commission (2018). Impact of EU-Funded Research and Innovation on ICT for Active and Health Ageing: The Top 25 Most Influential Projects. Available at: https://publications.europa.eu/en/publication-detail//publication/c86da91e-41eb-11e8-b5fe-01aa75ed71a1

Eurostat, http://ec.europa.eu/eurostat/web/main/home.Last accessed: October 2017.

Formosa, M. (2014). Four decades of Universities of the Third Age: past, present, future. Ageing\&Society, 34(1), 4266.

Formosa, M. (2012) Education and Older Adults at the University of the Third Age, Educational Gerontology, 38:2, 114-126, DOI: 10.1080/03601277.2010.515910

Gonzalez, A., Paz Ramirez, M. \& Viadel, V. (2012). Attitudes of the Elderly toward Information and Communications. Educational Gerontology, 38(9), 585-94.

Gitto, L., 2018. Older adults' education and its relation to quality of life; an Italian example. Journal of Aging and Long Term Care, 1(1), 19-33.

Grossman, M. (2000) The Human Capital Model, in Handbook of Health Economics, ch.7.

Heart, T., Kalderon, E., 2013. Older adults: Are they ready to adopt health-related ICT?Int J Med Inf 82, e209-e231.

Hernández-Encuentra, E., Pousada, M.\&Gómez-Zúñiga, B. (2009). ICT and Older People: Beyond Usability. Educational Gerontology 35(3), 226-45.

Heyn Billipp, S. (2001). The psychosocial impact of interactive computer use within a vulnerable elderly population: a report on a randomized prospective trial in a home health care setting. Public Health Nursing,18(2), 138-45.

Irizarry, C., Downing, A.R. \& West, D. (2001). Use of the Internet by Rural South Australians. Australasian Journal on Ageing.

Jones, A. (2007) Applied econometric for health economists, a practical guide. Office of Health Economics. https://www.ohe.org/publications/applied-econometrics-health-economists-practical-guide.

Konrad, K.\&Wittowsky, D. (2017). Virtual mobility and travel behavior of young people - Connections of two dimensions of mobility. Research in Transportation Economics, 68, 11-17.

Lenhart, A., Horrigan, J., Raine, L., Allen, K., Boyce, A., Madden, M., et al. (2003). The Ever-shifting Internet Population: A New Look at Internet Access and the Digital Divide. Pew Internet and American Life Project. Available at http://www.pewInternet.org/ /media//Files/Reports/2003/PIP_Shifting_Net_Pop_Report.pdf.pdf

Martinez-Pecino, R., Lera, M.J.\& Martinez-Pecino, M. (2012).Active seniors and mobile phone interaction. Social Behavior and Personality, 40(5), 875-80.

Mason, M., Sinclair D.\& Berry C.(2012). Nudge or Compel? Can Behavioural Economics Tackle the Digital Exclusion of Older People?, International Longevity Centre - UK, London. Available at:

www.ilcuk.org.uk/files/Nudge_or_compel.pdf.

Mayhorn, C. Stronge, A.J., Collins McLaughlin, A. \& Rogers, W.A. (2004). Older adults, computer training, and the systems approach: A formula for success. Educational Gerontology, 30(3), 185-203.

Morris, A., Goodman, J.\&Brading, H. (2007). Internet use and non-use: views of older users. Universal Access in the Information Society, 6(1), 43-57.

Nguyen, T., Irizarry, C., Garrett, R., \& Downing, A. (2015). Access to mobile communications by older people. Australasian Journal on Ageing, 34(2), E7-E12. doi: 10.1111/ajag.12149

Orley, J. \&Kuyken, W. (1994). Quality of Life Assessment: International Perspectives. Proceedings of the JointMeeting Organized by the World Health Organization and the Fondation IPSEN in Paris, July 2-3, 1993. Available at: https://link.springer.com/book/10.1007\%2F978-3-642-79123-9

Pannor Silver, M. (2014). Socioeconomic status over the life course and internet use in older adulthood, Ageing \& Society, 34(6), 1019-34. 
Phillipson, C. \&Ogg, J. (2010). Active Ageing and Universities: Engaging Older Learners. Universities UK, London. Available at: https://dera.ioe.ac.uk/26269/1/ActiveAgeing.pdf

Rosseau, G.K. \&Rogers, W.A.(1998).Computer usage patterns of university faculty members across the life span.Computers in human behavior, 14(3), 417-28

Santos, B., IostPavarini, S.C., Brigola, A.G., Souza Orlandi, F. \& Inouye, K. (2014). Quality of life in elderly in the literacy process. Dementia \& Neuropsychologia, 8(2), 169-74.

Selwyn, N., Gorard, S. \& Furlong, J., 2003. The information aged: Older adults' use of information and communications technology in everyday life. School of Social Sciences Working Papers Series, 36. Cardiff: Cardiff University. Available at: http://orca.cf.ac.uk/78079/, 2003.

Selwyn, N., Gorard, S., Furlong, J.\&Madden, L. (2003). Older adults' use of information and communications technology in everyday life. Ageing \& Society 23(5),561-582.

Skevington, S.M., Lotfy, M.\& O'Connell, K.A. (2004). The World Health Organization's WHOQOL-BREF quality of life assessment: Psychometric properties and results of the international field trial A Report from the WHOQOL Group. Quality of Life Research, 13(2), 299-310.

Szabo, S. (1996). The World Health Organisation Quality of Life (WHOQOL) Assessment Instrument. In Spilker B. (ed.), Quality of Life and Pharmaeconomics in Clinical Trials (2nd edition), Lippincott-Raven Publishers, Philadelphia, New York.

Swindell, R., Thompson J. (1995) An international perspective on the University of the Third Age, Educational Gerontology, 21:5, 429-447, DOI: 10.1080/0360127950210505

Vimarlund, V. \&Olve, N.(2005). Economic analyses for ICT in elderly healthcare: questions and challenges, Health Informatics Journal, 11(4), 309-321.

The WHOQOL Group (1994a). Development of the WHOQOL: Rationale and current status. International Journal of Mental Health 23(3), 24-56.

The WHOQOL Group(1994b). The development of the World Health Organization quality of life assessment instrument (the WHOQOL). In J. Orley and W. Kuyken (eds.),Quality of Life Assessment: International Perspectives. Heidelberg: Springer Verlag.

The WHOQoL Group (1998) Development of the World Health Organization WHOQOL-BREF quality of life assessment. Psychological Medicine, 28(3), 551-558.

World Health Organization. Division of Mental Health. (1996). WHOQOL-BREF: introduction, administration, scoring and generic version of the assessment: field trial version. Geneva: World Health Organization. Available at: http://www.who.int/iris/handle/10665/63529.

WHO (2002), Active Ageing: A Policy Framework World, Madrid, Spain, April 2002

Zielinska-Wieczkowska, H., Kedziora-Kornatowska, K.\&Ciemnoczolowski, W. (2011). Evaluation of quality of life (QoL) of students of the University of Third Age (U3A) on the basis of socio-demographic factors and health status. Archives of Gerontology and Geriatrics, 53(2), e198-e202. 